\title{
Late-season Strawberry Production Using Day-neutral Cultivars in High-elevation High Tunnels
}

\author{
Daniel Rowley, Brent L. Black ${ }^{1}$, and Dan Drost \\ Plants, Soils and Climate Department, Utah State University, 4820 Old Main \\ Hill, Logan, UT 84322-4820
}

\author{
Dillon Feuz \\ Department of Applied Economics, Utah State University, Logan, UT 84322- \\ 3530
}

Additional index words. Fragaria $\times$ ananassa, protected cultivation

\begin{abstract}
Small-scale fruit and vegetable growers increasingly use high tunnels to expand production windows and exploit demand for local produce. Day-neutral cultivars, high tunnels, low tunnels, and targeted heating were investigated in North Logan, UT (lat. $41.766^{\circ} \mathrm{N}, 1405 \mathrm{~m}$ elevation, 119 freeze-free days) to extend the availability of local strawberries. Day-neutral cultivars Albion, Evie 2, Seascape, and Tribute were springplanted in an annual hill system both inside and outside of high tunnels. Within the high tunnels, low tunnels and targeted root zone heating were tested in replicated plots. During the summer months, plastic was removed from the high tunnels and replaced with shadecloth. Treatments were evaluated for yields, fruit size, and production season. Fruit production in the tunnels began in late May and continued sporadically until December. Combinations of high and low tunnels provided more hours of optimal growing conditions than high tunnels alone, but managing the combination to maintain optimum temperatures proved difficult with temperatures often exceeding the optimum for strawberry. Targeted root zone heating efficiently increased root and canopy temperatures, preventing flower bud damage during extreme cold events, but did not significantly improve total season yields. Of the cultivars tested, 'Evie 2' and 'Seascape' had the most consistent yields and acceptable fruit size. Economic analysis indicated that growing spring-planted day-neutral strawberries in high tunnels was marginally profitable, whereas field production at this location would be a money-losing enterprise.
\end{abstract}

Although the fresh market strawberry industry in the United States is overwhelmingly dominated by California and Florida, smallscale production continues throughout much of North America, particularly in proximity to urban centers where fresh local produce commands premium prices. Demand for local produce continues to increase with the developing local food movement despite environmental conditions in many areas that are less than ideal for strawberry production. Ideal conditions for strawberries occur when temperatures are between 20 and $26{ }^{\circ} \mathrm{C}$. Sub-

Received for publication 30 June 2011. Accepted for publication 29 Aug. 2011.

Funding was provided by grants from the Western Sustainable Agriculture Research and Education (SARE) program, the Utah Dept. of Agriculture and Food-Specialty Crop Block Grant program and from the Utah Agricultural Experiment StationUtah State University (journal paper number 8329). Use of trade names does not imply an endorsement of the products named or criticism of similar ones not named.

We gratefully acknowledge the technical assistance of James Frisby.

This paper is a portion of a M.S. thesis submitted by D. Rowley.

${ }^{1}$ To whom reprint requests should be addressed; e-mailbrent.black@usu.edu. optimal temperatures (less than $20^{\circ} \mathrm{C}$ ) retard the growth and development of both the strawberry plant and fruit, whereas superoptimal temperatures (greater than $35^{\circ} \mathrm{C}$ ) cause the strawberry plant to stop growing (Galletta and Bringhurst, 1990)

Fall-planted June-bearing cultivars in an annual hill production system have proven effective for focusing fruit production in the early spring (Black et al., 2002; Poling, 1993; Stevens et al., 2011), but length of fruiting season is limited by photoperiod and temperature (Durner et al., 1984). Alternatively, day-neutral cultivars are insensitive to photoperiod and continue to flower as long as temperatures are between 4 and $29{ }^{\circ} \mathrm{C}$ (Hancock and Handley, 1998; Pritts and Dale, 1989). In many production areas including the northeast United States, day-neutral cultivars are increasingly being used to extend the growing season and produce strawberries throughout the summer. Day-neutral plants are established in the early spring, come into production near the end of the June-bearing production season, and continue to fruit through the summer and fall months (Pritts and Dale, 1989).

Conditions in the high-elevation valleys of the Intermountain West region of the United States (Utah, Idaho, Nevada, western Colorado) are particularly challenging for strawberry production. Early spring temperatures are generally suboptimal and transition rapidly to summer temperatures that are typically superoptimal (Moller and Gillies, 2008). Wide diurnal temperature fluctuations in early spring also limit strawberry production in the region, and there is not sufficient water available for spring frost protection. The production window for field-grown June-bearing strawberries also coincides with peak national production and depressed wholesale prices (Pollack and Perez, 2008). The short growing season and depressed prices often make strawberry production in the region only marginally profitable.

High tunnels have been successfully used to manipulate temperature and extend the growing season for a number of crops, including flowers (Rasmussen and White, 2006), vegetables (Orzolek et al., 2006), and small fruits (Demchak, 2009; Demchak et al., 2006). We previously showed that high tunnels could be used effectively in high-elevation, arid regions in the western United States to advance the production season of June-bearing strawberries with the added benefit of protecting early blossoms from frost, resulting in increased early and total yield and greater potential profitability (Rowley et al., 2010b, 2010c). Extending the production season later into the summer and fall would require day-neutral cultivars and additional temperature management strategies. Low tunnels can be used inside high tunnels to further increase temperatures for plant growth and have been used in a number of crops with varied success (McIntosh and Klingaman, 1993; Roberts and Whitworth, 1993; Takeuchi and Motsenbocker, 2005). Low tunnels are typically only 40 to $50 \mathrm{~cm}$ tall and cover only one row or one bed of strawberries (Galletta and Bringhurst, 1990). Replacing high-tunnel plastic with shadecloth during the warmest summer months is another method for passive manipulation of growing temperatures.

The focus of this study was to optimize management systems for late-season extension of strawberry production in the Intermountain West region of the United States. Specific objectives for this study were to quantify the season extension benefits that result from using day-neutral cultivars in high tunnels, to identify a suitable day-neutral cultivar for high tunnel production, to examine temperature manipulation methods for use in combination with high tunnels to optimize growing conditions, and to examine the possibility of using summer-planted plug plants for increased fall production.

\section{Materials and Methods}

In 2008 , three raised beds $60 \mathrm{~cm}$ wide and $20 \mathrm{~cm}$ high were formed in a $4.3 \mathrm{~m} \times 12.8-\mathrm{m}$ high tunnel (Black et al., 2008) located on the Utah Agricultural Experiment Station Greenville Research Farm, in North Logan, UT (lat. $41.76^{\circ} \mathrm{N}, 1405 \mathrm{~m}$ elevation). Beds were on 1.35 -m centers covered with black plastic mulch with drip irrigation. The beds were divided into 24 plots arranged in a split-block design. Each row was considered a replication and was divided into two main plots that were covered with a low tunnel or left uncovered. Main plots were then further divided into four subplots 
consisting of eight plants of one of four cultivars. The resulting design allowed for blocking by location within the tunnel.

Dormant bare root strawberry plants were transplanted in late February in offset double rows with $30-\mathrm{cm}$ spacing within and between rows $\left(4.8\right.$ plants $\left./ \mathrm{m}^{2}\right)$. Plots were managed as a spring-planted annual hill system patterned after the day-neutral production methods used in Ontario, Canada (Pritts and Dale, 1989). The cultivars selected for evaluation were Albion, Seascape, Evie 2, and Tribute (Galletta, 1997; Shaw and Larson, 2006) to represent California, European and eastern U.S. cultivars, respectively.

After planting, low tunnels were constructed by bending a $1.5-\mathrm{m}$ piece of $1.25-\mathrm{cm}$ diameter steel electrical conduit to form an inverted $U$ shape that was $\approx 75 \mathrm{~cm}$ wide and $40 \mathrm{~cm}$ tall. Two $60-\mathrm{cm}$ pieces of $1-\mathrm{cm}$ diameter rebar were driven into the ground on opposite sides of the bed, and the arch was set on top of the protruding ends. Arches were placed every $1.5 \mathrm{~m}$ along the bed and twine was stretched between arches to support a piece of 2-mil construction-grade clear plastic. Low tunnels were used until mid-May and then replaced over the appropriate plots in mid-September but were removed during the summer. Low tunnels were managed in much the same way as the high tunnel. The target plant canopy temperature was $20^{\circ} \mathrm{C}$ and ventilation of both low and high tunnels was managed on a daily basis to best maintain the target temperature.

Data on yield, fruit size, and fruit quality for 2008 indicated that 'Tribute' was not a viable cultivar for high tunnel strawberry production at this location, and the cultivar was omitted from the 2009 plantings. Additionally, low plant vigor was observed in the strawberry plants late in the 2008 season. It was determined that in 2009 , half of the plants would be replanted with plug plants after the spring flush of production in an effort to obtain improved vigor and production into the fall.

Therefore, the 2009 experiment was modified as follows. Dormant bare root plants of day-neutral cultivars Albion, Seascape, and Evie 2 were planted in a split-split plot design on 26 Feb. 2009 in a $4.3-\mathrm{m}$ wide $\times 14.6-\mathrm{m}$ long high tunnel. The high tunnel was arranged such that there were three $14.6-\mathrm{m}$ long beds in an east-west orientation. Plants were planted in the annual hill system as described above, with bed spacing of $1.35 \mathrm{~m}$ (center to center) and plant spacing at $30 \mathrm{~cm}$ in and between rows $\left(4.8\right.$ plants $\left./ \mathrm{m}^{2}\right)$. Each row was considered a replication and was divided in half to form main plots of spring planted and spring planted with summer replant. Main plot treatments were planted on $26 \mathrm{Feb}$. 2009, and those plots designated for summer replant were removed on 28 July 2009 and replanted with plug plants on 30 July 2009. Each main plot was divided into subplots that were either covered with a low tunnel or left uncovered. In addition, soil heating cables (Mor Electric Heating Assoc., Inc., Comstock Park, MI) were installed in the beds under the low tunnels. Soil heat cables were buried 2 to $3 \mathrm{~cm}$ deep before planting in late February. Each bed contained three strands of cable that were arranged
Table 1. Monthly air temperature extremes $\left({ }^{\circ} \mathrm{C}\right)$ for the 2009 season for high tunnels $(\mathrm{HT})$, low tunnels within high tunnels (LT), and in the field at the Greenville Research Farm, North Logan, UT. ${ }^{z}$

\begin{tabular}{|c|c|c|c|c|c|c|}
\hline & \multicolumn{3}{|c|}{ Maximum } & \multicolumn{3}{|c|}{ Minimum } \\
\hline & $\overline{\mathrm{HT}}+\mathrm{LT}$ & HT & $\overline{\text { Field }}$ & $\mathrm{HT}+\mathrm{LT}$ & HT & Field \\
\hline$\overline{\text { March }}$ & 51.5 & 39.0 & 25.0 & -0.4 & -4.8 & -9.0 \\
\hline April & 31.1 & 29.6 & 22.0 & 8.3 & 1.3 & -1.7 \\
\hline May & 40.3 & 38.9 & 36.1 & 5.3 & 4.5 & 1.3 \\
\hline June & $-^{y}$ & 32.1 & 35.9 & $-^{y}$ & 6.6 & 6.4 \\
\hline July & - & 36.8 & 43.1 & - & 8.7 & 8.8 \\
\hline August & - & 37.2 & 43.5 & - & 5.0 & 4.5 \\
\hline September & 35.0 & 34.2 & 36.5 & 3.2 & 3.2 & 1.5 \\
\hline October & 36.7 & 28.5 & 29.2 & 4.3 & -0.8 & -2.4 \\
\hline November & 39.4 & 29.0 & 24.5 & 2.3 & -4.8 & -7.4 \\
\hline December & 37.2 & 26.9 & 13.5 & -4.0 & -13.0 & -23.6 \\
\hline
\end{tabular}

${ }^{\mathrm{z}} \mathrm{LT}$ plots also included soil heating cables set at $4{ }^{\circ} \mathrm{C}$. Air temperature measurements were taken using shielded thermocouples $23 \mathrm{~cm}$ above the ground.

${ }^{y}$ From June through August, low tunnels were not used, and high tunnels were covered with shadecloth.

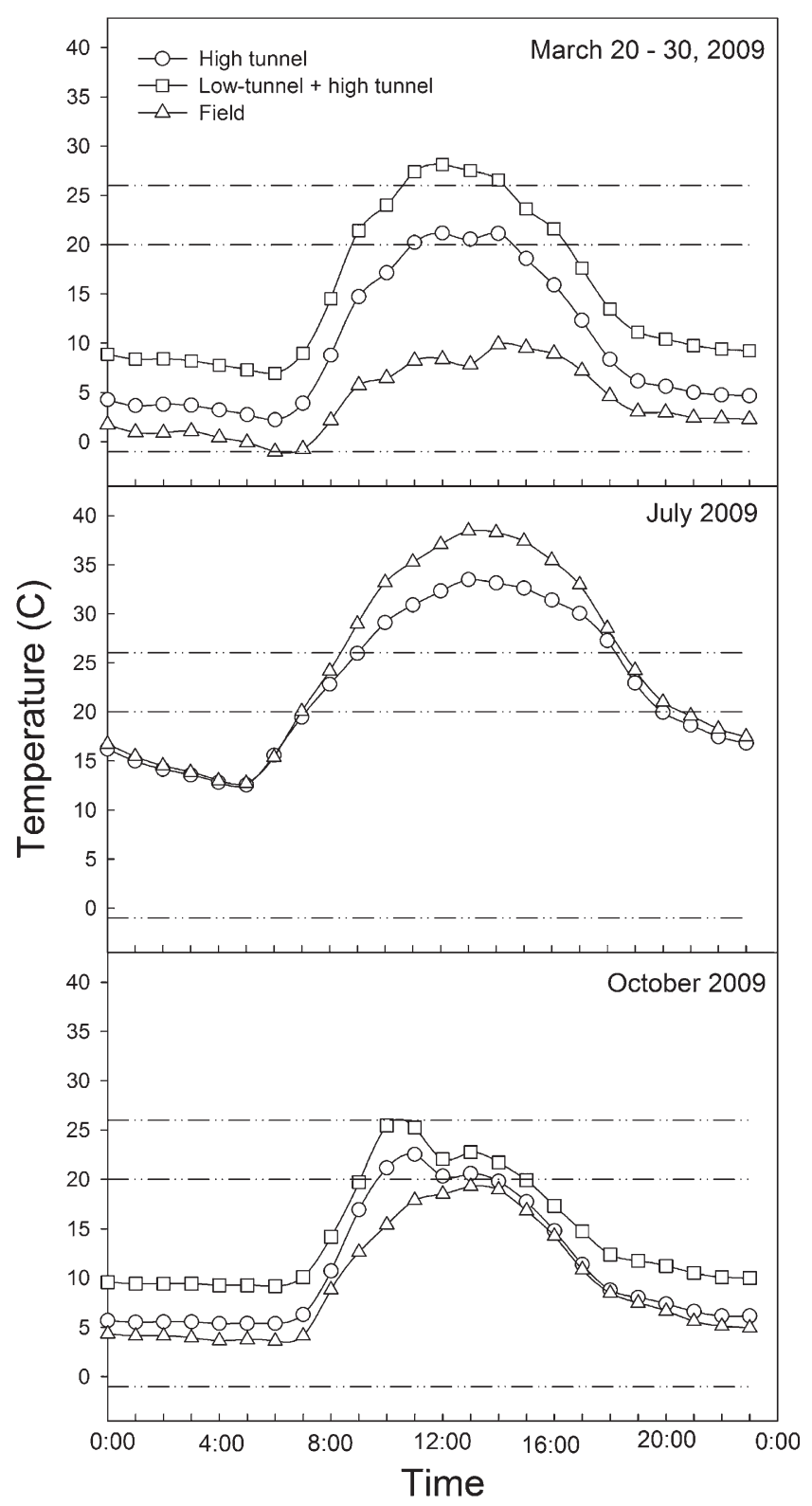

Fig. 1. Average diurnal air temperature fluctuations at 23-cm height for selected time periods in 2009 . Horizontal lines indicate optimum and critical temperatures for strawberry. Low tunnels were used until $\approx 15$ May and again beginning $\approx 15$ Sept. Soil heating cable was activated at soil temperatures less than $4{ }^{\circ} \mathrm{C}$. Forty percent light reduction shadecloth was used from $\approx 1$ June through 31 Aug. 
such that one strand was in the middle of the bed with the other strands being offset on each side by $23 \mathrm{~cm}$. The heating cables were controlled by a soil thermostat that was activated when root zone temperatures dropped below $4{ }^{\circ} \mathrm{C}$. Each subplot was further divided into six-plant sub-subplots randomly assigned to one of the three cultivars.

In both production years, an outside field comparison was planted. Planting occurred as soon as conditions allowed with planting dates on 28 May 2008 and 1 May 2009. Plants were in offset double rows on raised beds similar to the high tunnels but with wider bed spacing. Beds for the field planting were on $1.5-\mathrm{m}$ centers (1.35 in high tunnels) with in- and between-row spacing maintained at $30 \mathrm{~cm}(4.4$ plants $/ \mathrm{m}^{2}$ density). For the 2008 season, the four cultivars (Albion, Evie 2, Seascape, and Tribute) were planted in a randomized block design with six blocks and eight-plant plots. In 2009, the outside field comparison was planted with three cultivars (Albion, Evie 2 , and Seascape) in a split plot design with three replicate blocks and six plants per plot. The main plot treatment consisted of covering the plants with floating rowcovers during periods of suboptimal temperatures compared with an uncovered control and cultivar as the subplot treatments.

Plug plants were produced as described by Rowley et al. (2010a). Briefly, mother plants were obtained from a commercial nursery and established in media-filled polyvinyl chloride gutters in a greenhouse maintained at $24 / 18^{\circ} \mathrm{C}$ day/night temperatures and a 16 -h photoperiod. Runner tips were collected $\approx 30 \mathrm{~d}$ before the scheduled tunnel planting date and transferred to 50-cell plug trays containing a 1:1:1 peat:perlite:vermiculite potting mix. Runner tips were maintained in a greenhouse under intermittent mist for $20 \mathrm{~d}$ and then removed from mist and held in the greenhouse for an additional $10 \mathrm{~d}$ before planting (Rowley et al., 2010a).

Both high tunnels and low tunnels were managed to maintain target temperatures between 20 and $26^{\circ} \mathrm{C}$. Thus, high tunnels were closed when temperatures were below $20^{\circ} \mathrm{C}$ and opened when temperatures were greater than $26^{\circ} \mathrm{C}$. During the summer months when daytime temperatures were consistently superoptimal, the plastic covering the tunnel was removed and replaced with $40 \%$ light-reducing shadecloth. The plastic was reattached to the tunnels in mid-September when outdoor temperatures began to decrease.

Irrigation was scheduled based on resistanceblock measurements (Watermark Model 200SS; Irrometer Company, Inc., Riverside, CA) taken between 20 - and $25-\mathrm{cm}$ depth in the strawberry bed with irrigation applied whenever soil moisture was below -30 centibars. Fertilizer was injected at each irrigation. During plant establishment, a soluble $20 \mathrm{~N}-20 \mathrm{P}-20 \mathrm{~K}$ mix with micronutrients was injected at a rate of 100 ppm N. Once flowering and fruiting had started, the fertilizer mix was adjusted to $10 \mathrm{~N}-30 \mathrm{P}-$ $20 \mathrm{~K}$ mix at a concentration of $50 \mathrm{ppm} \mathrm{N}$. Chelated iron (Sprint 138; Becker Underwood Inc., Ames, IA) was injected periodi-

Table 2. The effect of high tunnels (HT), low tunnels within high tunnels (LT) and cultivar on 2008 yields (g/plant) during early summer (20 May to 12 Aug.), late summer (13 Aug. to 12 Oct.), and fall (13 Oct. to 15 Dec.).

\begin{tabular}{lcccr}
\hline & \multicolumn{3}{c}{ Yield g/plant } \\
\cline { 2 - 5 } & Early summer & Late summer & Fall & Total \\
\hline High tunnel (HT) & $256 \mathrm{~b}^{\mathrm{y}}$ & 247 & 165 & $668 \mathrm{~b}$ \\
HT + low tunnel (LT) & $335 \mathrm{a}$ & 257 & 196 & $788 \mathrm{a}$ \\
& & & 174 & $531 \mathrm{~b}$ \\
Albion & $156 \mathrm{~b}$ & 201 & 142 & $856 \mathrm{a}$ \\
Evie 2 & $396 \mathrm{a}$ & 318 & 243 & $833 \mathrm{a}$ \\
Seascape & $348 \mathrm{a}$ & 242 & 164 & $693 \mathrm{ab}$ \\
Tribute & $283 \mathrm{a}$ & 246 & & \\
& & & & 0.028 \\
Analysis of variance & & & & 0.001 \\
Factor & & & & 0.001 \\
$\quad$ Tunnel & 0.010 & 0.822 & $0.045^{\mathrm{z}}$ & 0.536 \\
$\quad$ Cultivar & 0.001 & 0.105 & & \\
$\quad$ Tunnel $\times$ cultivar & 0.274 & & & \\
\hline
\end{tabular}

${ }^{z}$ See Table 3 for breakdown of treatment interaction.

${ }^{\mathrm{y}}$ Main effect means followed by the same letter are not significantly different at $P=0.05$.

cally to alleviate chlorosis. Plants were scouted periodically for developing insect and disease issues and treated as needed. During the fall season, fungicide applications (Captan; Southern Agricultural Insecticides, Hendersonville, NC; and Thionex 50W; MANA Crop Protection, Raleigh, NC) were made to control Botrytis fruit rot. Because the high tunnels were opened daily during much of the pollination season, supplemental pollinators were not used.

Throughout both growing seasons, ripe fruit was harvested twice weekly. Total mass of ripe fruit was determined for individual plots and average fruit size was determined on a 10-fruit sample. Runners were counted and removed on a weekly basis, and monthly crown counts were made throughout the growing season. Plant growth data were analyzed using the PROC GLM procedure of the SAS statistical analysis software (SAS Institute Inc., Cary, NC) with a statistical significance of $P=0.05$. Each plot was also equipped with shielded thermocouples for measuring air temperature at $0.23 \mathrm{~m}$ above the ground with thermocouples attached to a data logger (CR1000; Campbell Scientific, Logan, UT).

Economic analysis. Based on the production system described, yields averaged over two seasons (from 'Evie 2'), and product sales data, a complete enterprise budget was developed. Fruit produced from the research plots was sold at an on-campus retail outlet to estimate local price points. Although research elsewhere suggests that consumers are willing to pay double the price for out-of-season fruit (Koester and Pritts, 2003), we found a 50\% premium over regular season prices to be more acceptable in the local market. Regular-season local fruit sold for $\$ 3.00$ for a 450 -g clamshell and out-of-season strawberries for $\$ 4.50$ per clamshell. Labor requirements were recorded for bed preparation, planting, temperature management, crop management, and harvesting. The tunnel costs were based on a low-cost high tunnel (Black et al., 2008) depreciated over 6 years. Irrigation system components were similarly depreciated. From these labor logs and local materials prices, a complete enterprise budget for day-neutral high-tunnel strawberries
Table 3. Interaction between low tunnel (LT) and cultivar treatments on Fall 2008 yields. ${ }^{\mathrm{z}}$

\begin{tabular}{lccc}
\hline & \multicolumn{3}{c}{ Yield g/plant } \\
\cline { 2 - 4 } & - Low tunnel & + Low tunnel & LT effect \\
\hline Albion & 137 & 211 & 75 \\
Evie 2 & 155 & 130 & -24 \\
Seascape & 206 & 280 & 74 \\
Tribute & 163 & 164 & 1 \\
\hline
\end{tabular}

zThis interaction is likely a result of increased gray mold infection under low tunnels in more susceptible cultivars Evie 2 and Tribute.

was calculated as well as a partial budget comparing day neutral production in high tunnels to field production.

\section{Results and Discussion}

High tunnels, high tunnels in combination with low tunnels, soil heating cables, and shadecloth were all used to modify temperatures for strawberry plants. Each of these strategies effectively altered plant growth temperatures. In addition to evaluating temperature modification treatments, four day-neutral cultivars were evaluated for use within the hightunnel environment.

Shielded thermocouples placed $23 \mathrm{~cm}$ above the strawberry beds measured temperatures within each main-plot treatment throughout the 2009 experiment. High tunnels alone effectively buffered against low temperature extremes in the early spring and late fall, providing as much as a $4.2{ }^{\circ} \mathrm{C}$ temperature increase compared with the outside (Table 1). High tunnels also increased the amount of time at which plants were held at optimal conditions. Diurnal temperature cycles averaged from 20 Mar. to 30 Mar. 2009 showed that high tunnels provided $4 \mathrm{~h}$ of temperatures greater than $20{ }^{\circ} \mathrm{C}$, whereas outdoor temperatures did not exceed $10{ }^{\circ} \mathrm{C}$ (Fig. 1). Likewise, October temperatures averaged $5 \mathrm{~h}$ per day above $20^{\circ} \mathrm{C}$, whereas outside daily temperature peak was typically below $20^{\circ} \mathrm{C}$. Both high and low tunnels were managed for a target temperature of 20 to $26^{\circ} \mathrm{C}$. However, as data for monthly extremes illustrate, there were significant challenges to passive temperature 
management. Temperature extremes (maximum and minimum) that exceeded the optimal range for strawberry production were recorded throughout the experiment (Table 1). Decisions regarding tunnel ventilation were generally made in the morning based on current conditions and the weather forecast. However, where changing cloud cover existed, rapid temperature changes occurred, particularly under low tunnels.

For the 2009 season, soil heating cable was installed in combination with low tunnels to further protect against low temperature extremes. Although a direct comparison of the effects of soil heating cable was not performed, a comparison of late fall temperatures recorded in the 2008 and 2009 studies suggests that the cables raised minimum temperatures by $\approx 4{ }^{\circ} \mathrm{C}$ (Rowley, 2010). The extreme minimum air temperature for Dec. 2009 was $-23.6^{\circ} \mathrm{C}$ outside the tunnel compared with $\approx 13.0^{\circ} \mathrm{C}$ in the high tunnel and

Table 4. The effect of high tunnels (HT), low tunnels within high tunnels (LT), and cultivar on 2008 mean berry size (g/berry) for the early summer (20 May to 12 Aug.), late summer (13 Aug. to 12 Oct.), and fall (13 Oct. to 15 Dec.) production periods.

\begin{tabular}{lccc}
\hline & \multicolumn{3}{c}{ Early } \\
& \multicolumn{1}{c}{ Late } & \\
& summer & summer & Fall \\
\hline High tunnel (HT) & 12.1 & 9.7 & 10.9 \\
HT + low tunnel (LT) & 13.5 & 9.6 & 11.8 \\
& & & \\
Albion & $15.6 \mathrm{a}^{\mathrm{z}}$ & $10.6 \mathrm{~b}$ & $13.7 \mathrm{a}$ \\
Evie 2 & $13.9 \mathrm{a}$ & $12.7 \mathrm{a}$ & $12.1 \mathrm{a}$ \\
Seascape & $13.9 \mathrm{a}$ & $9.5 \mathrm{~b}$ & $12.3 \mathrm{a}$ \\
Tribute & $7.9 \mathrm{~b}$ & $5.8 \mathrm{c}$ & $7.4 \mathrm{~b}$ \\
& & & \\
Analysis of variance & & & \\
Factor & & $P$ & \\
$\quad$ Tunnel & 0.297 & 0.853 & 0.174 \\
Cultivar & $<0.001$ & $<0.001$ & $<0.001$ \\
$\quad$ Tunnel $\times$ cultivar & 0.211 & 0.951 & 0.135 \\
\hline
\end{tabular}

${ }^{\mathrm{z}}$ Main effect means followed by the same letter are not significantly different at $P=0.05$.

Table 5. The effect of summer replant, high tunnels (HT), low tunnels within high tunnels (LT), and cultivar on 2009 yields (g/plant) for early summer (20 May to 12 Aug.), late summer (13 Aug. to 12 Oct.), and fall (13 Oct. to 15 Dec.). ${ }^{\mathrm{z}}$

\begin{tabular}{|c|c|c|c|c|}
\hline & \multicolumn{4}{|c|}{ Yield g/plant } \\
\hline & Early summer & Late summer & Fall & Total \\
\hline Summer replant & 243 & - & 41 & 284 \\
\hline Not replanted & 243 & 149 & 50 & 460 \\
\hline High tunnel (HT) & 254 & 140 & 44 & 369 \\
\hline $\mathrm{HT}+$ low tunnel (LT) & 232 & 157 & 48 & 375 \\
\hline Albion & $152 \mathrm{c}^{\mathrm{y}}$ & $103 \mathrm{~b}$ & 38 & $244 \mathrm{~b}$ \\
\hline Evie 2 & 339 a & $221 \mathrm{a}$ & 53 & $526 \mathrm{a}$ \\
\hline Seascape & $237 \mathrm{~b}$ & $121 \mathrm{~b}$ & 46 & $346 b$ \\
\hline Factor & & $P$ & & \\
\hline Summer replant & - & - & 0.533 & 0.056 \\
\hline Cover & 0.296 & 0.622 & 0.725 & 0.892 \\
\hline Summer replant $\times$ cover & - & - & 0.162 & 0.668 \\
\hline Cultivar & $<0.001$ & 0.018 & 0.133 & $<0.001$ \\
\hline Summer replant $\times$ cultivar & - & - & 0.162 & 0.964 \\
\hline Cover $\times$ cultivar & 0.085 & 0.262 & 0.165 & 0.668 \\
\hline Summer replant $\times$ cultivar $\times$ cover & & - & 0.762 & 0.866 \\
\hline
\end{tabular}

${ }^{2}$ The LT treatment also included soil heating cables set to maintain temperatures at or above $4{ }^{\circ} \mathrm{C}$.

${ }^{y}$ Means followed by the same letter are not significantly different at $P=0.05$. lasted through the week of 15 Dec. ( 9 weeks) with the latest large harvest on 3 Nov.

Field production during the 2008 season was late, limited, and most berries were not of marketable size. Marketable berry size was considered to be greater than $10 \mathrm{~g} /$ berry. Field production ranged from 11 to $114 \mathrm{~g} /$ plant for 'Albion' and 'Evie 2', respectively, with essentially all of the production occurring during the late-summer period (data not shown, see Rowley 2010). Field production in 2009 was significantly higher than for 2008, ranging from 213 to $310 \mathrm{~g} /$ plant for 'Seascape' and 'Evie 2', respectively. Yields in 2009 were divided between the early-summer and latesummer time periods. Although the use of floating rowcovers in the field did not significantly improve total yields, production was somewhat earlier with more of the production shifted from the midsummer to the earlysummer period (data not shown). Planting in 2008 was delayed as a result of wet spring conditions that delayed preparing planting beds. Higher field production in 2009 likely resulted from the earlier planting date compared with the 2008 season. The earlier planting date in 2009 was possible because bed preparation was carried out in the fall. Both 2008 and 2009 data indicated that peak day-neutral harvest occurred $\approx 3$ to 4 weeks after peak harvest for field-planted June bearers at the same location (Rowley et al., 2010b). Thus, using day-neutrals extended the strawberry season later. Although the experiment was not designed to directly compare field production with high tunnel production, yields in the tunnels were consistently

Table 6. The effect of summer replant, high tunnels (HT), low tunnels within high tunnels (LT), and cultivar on 2009 mean berry size (g/berry) during early summer (20 May to 12 Aug.), late summer (13 Aug. to 12 Oct.), and fall (13 Oct. to 15 Dec.).

\begin{tabular}{lccl}
\hline & Early & Late & \\
& Summer & Summer & Fall $^{\text {z }}$ \\
\hline Replant & - & - & 8.8
\end{tabular}

Spring planted

8.8
11.7

$\begin{array}{llrr}\text { High tunnel (HT) } \quad 16.8 \mathrm{a}^{\mathrm{y}} & 11.1 \mathrm{a} & 10.8 \\ \mathrm{HT}+\mathrm{low} & 14.6 \mathrm{~b} & 9.2 \mathrm{~b} & 9.7\end{array}$

tunnel (LT)

$\begin{array}{lrrr}\text { Albion } & 16.4 \mathrm{a} & 10.1 \mathrm{ab} & 10.2 \mathrm{ab} \\ \text { Evie 2 } & 17.0 \mathrm{a} & 11.9 \mathrm{a} & 11.6 \mathrm{a} \\ \text { Seascape } & 13.8 \mathrm{~b} & 8.5 \mathrm{~b} & 9.0 \mathrm{~b}\end{array}$

Analysis of variance

Plantin

Cover

Planting $\times$ cover

Cultivar

Planting $\times$

cultivar

$\begin{array}{llll}\text { Cover } \times \text { cultivar } & 0.299 & 0.264 & 0.775\end{array}$

$\begin{array}{llll}\text { Planting } \times & - & - & 0.436\end{array}$ cultivar $\times$ cover

${ }^{2}$ Arithmetic mean was used to report berry weight and log-transformed data were used to determine significance.

${ }^{y}$ Means in a column followed by the same letter are not significantly different at $P=0.05$. 
Table 7. High-tunnel day-neutral strawberry enterprise budget for a $125-\mathrm{m}^{2}$ low-cost high tunnel. ${ }^{\mathrm{z}}$

\begin{tabular}{|c|c|c|c|c|}
\hline & Unit & Quantity & Price & \\
\hline In-season sales (June to -September) & 455-g clamshell & 748 & $\$ 3.00$ & $\$ 2244.00$ \\
\hline Late out-of-season sales (October to November) & & 134 & $\$ 4.50$ & $\$ 603.00$ \\
\hline Total sales & & & & $\$ 2847.00$ \\
\hline \multicolumn{5}{|l|}{ Supplies } \\
\hline \multicolumn{5}{|l|}{ Preplant and preparation costs } \\
\hline Soil test & each & 1 & $\$ 14.00$ & $\$ 14.00$ \\
\hline Fuel & gal. & 0.38 & $\$ 3.00$ & $\$ 1.13$ \\
\hline Preplant soil amendments & lbs & 2.25 & $\$ 15.00$ & $\$ 33.75$ \\
\hline Plastic mulch & $\mathrm{ft}$ & 281 & $\$ 0.05$ & $\$ 14.06$ \\
\hline Drip tape & $\mathrm{ft}$ & 563 & $\$ 0.05$ & $\$ 28.13$ \\
\hline \multicolumn{5}{|l|}{ Strawberry establishment and growth } \\
\hline Dormant bare-root plants & each & 563 & $\$ 0.10$ & $\$ 56.25$ \\
\hline Fertilizer (19 lbs $20 \mathrm{~N}-20 \mathrm{P}-20 \mathrm{~K}, 6 \mathrm{lbs} 10 \mathrm{~N}-30$ & $\mathrm{P}-20 \mathrm{~K})$ & & & $\$ 32.91$ \\
\hline Fungicide (Captan at $0.84 \mathrm{lbs}$ and Thionex W & at $0.06 \mathrm{lbs})$ & & & $\$ 8.71$ \\
\hline \multicolumn{5}{|l|}{ Harvest } \\
\hline Clamshells & each & 882 & $\$ 0.21$ & $\$ 185.22$ \\
\hline Total supplies & & & & $\$ 374.15$ \\
\hline \multicolumn{5}{|l|}{ Labor ( $\$ 10$ per hour) } \\
\hline Preplant and preparation costs & & 29.75 & & $\$ 297.50$ \\
\hline Strawberry establishment and growth & & 65 & & $\$ 650.00$ \\
\hline Strawberry harvest & & 106.8 & & $\$ 1067.98$ \\
\hline Post-harvest & & 4.5 & & $\$ 45.00$ \\
\hline Total labor & & & & $\$ 2060.48$ \\
\hline \multicolumn{4}{|l|}{ Annual operating expenses (supplies and labor) } & $\$ 2434.63$ \\
\hline \multicolumn{4}{|c|}{ Annual depreciation cost of high tunnel ( 6 years structure, 3 years plastic) } & $\$ 241.17$ \\
\hline \multicolumn{3}{|l|}{ Annual depreciation cost of irrigation system } & & $\$ 58.82$ \\
\hline Total expenses & & & & $\$ 2734.62$ \\
\hline Net income & & & & $\$ 112.38$ \\
\hline \multicolumn{5}{|l|}{ Partial budget for field production } \\
\hline Total sales & & 250 & $\$ 3.00$ & $\$ 750.00$ \\
\hline Supplies & & & & $\$ 241.15$ \\
\hline Labor & & & & $\$ 1219.48$ \\
\hline Annual depreciation cost of irrigation system & & & & $\$ 58.82$ \\
\hline Total expenses & & & & $\$ 1519.45$ \\
\hline Net income & & & & $\$ 769.45$ \\
\hline
\end{tabular}

higher than in the field. For example, high tunnel yields of 'Evie 2' were 786 and $606 \mathrm{~g}$ / plant in 2008 and 2009, respectively, compared with 114 and $310 \mathrm{~g} /$ plant in the field. Ballington et al. (2008) reported yields of 710 $\mathrm{g} /$ plant for fall-planted 'Seascape' in the field in North Carolina. These yields are comparable to Utah high-tunnel yields for 'Evie 2' but are significantly greater than field production plots at this location (data not shown).

During the 2008 season, significantly greater early summer and total-season yields were obtained when strawberries were grown under low tunnels inside the high tunnels compared with high tunnels alone. Averaged across all cultivars, low tunnels increased early summer yield by $79 \mathrm{~g} /$ plant and total yield by 120 $\mathrm{g} /$ plant (Table 2). Fall yields showed a significant low tunnel $\times$ cultivar interaction (Table 3 ), which is attributed to increased infections of gray mold in 'Evie 2' and 'Tribute' as a result of the high humidity environment under the low tunnel. Late yields for 'Tribute' were not improved by low tunnels, whereas marketable yields of 'Evie 2' were reduced by an estimated $50 \%$ to $75 \%$. Yields for both 'Albion' and 'Seascape' were greater under the low tunnels than outside the low tunnels in the high tunnels (Table 3). Fruit size in 2008 was determined by cultivar rather than the low tunnel treatment (Table 4).
During the 2009 season, soil heat cables were evaluated as a method to further enhance plant protection beneath the low tunnels. Although heat cables were effective in minimizing extreme low temperatures (data not shown; see Rowley, 2010), yields were not significantly affected by targeted heat addition (Table 5). The lack of response in our study may be attributable to having the soil thermostat set too low $\left(4{ }^{\circ} \mathrm{C}\right)$. Additional work in this area is required. Berry size was significantly smaller under low tunnels compared with high tunnels alone (Table 6). The cause of decreased berry size and lack of significantly increased summer yields is not known but may have been the result of temperature extremes reached under the low tunnels during plant establishment (March to May, Table 1).

Although the combination of low tunnels and soil heat cable did not significantly affect yield from May through Nov. 2009 (Table 5), plants provided with additional soil heat and protected with low tunnels were observed to flower and fruit into Apr. 2010. Low tunnels and soil heat cable appeared to protect flowers in the lower levels of the canopy during periods of extreme low winter temperatures when flowers in the upper canopy and in the high tunnels (without additional protection) were killed. Although low tunnels and soil heat cable facilitated year-round production, yields from December to February were extremely low, fruit size was small, and quality was poor (data not shown).

During the 2008 fall production period, lack of plant vigor appeared to limit production. In 2009, a subset of plots was replanted in an effort to increase fall vigor and yields. Plants were replaced with new plug plants after the first large flush of fruit was produced. Replanting with plug plants did not significantly improve fall production (Table 5).

Cultivar comparison. Table 2 shows the 2008 yield results for the four cultivars evaluated. With the exception of fall yields, which were dramatically reduced as a result of gray mold, 'Evie 2' had the highest yields. Average berry size was highest for 'Albion' in the early summer and fall of 2008. However, 'Evie 2' fruit size was significantly larger than both 'Albion' and 'Seascape' during the late-summer period. 'Tribute' produced significantly smaller berries in all periods (Table 4). In 2009, 'Evie 2' had both the highest early-summer and latesummer yields (Table 5) and the highest mean fruit size (Table 6).

Economic analysis. Based on the management system described here, net income for a $125-\mathrm{m}^{2}$ low-cost high tunnel without low tunnels or soil heat cable was estimated to be $\$ 112$ (Table 7). This includes total sales of $\$ 2847$ less total expenses of $\$ 2735$. Total expenses include annual operating expenses or the expenses associated with yearly production as well as the annual depreciation costs of the high tunnel and irrigation system assuming a useful life of 6 years ( 3 years for the plastic film).

A partial budget for field production is also shown in Table 7 (For a detailed budget, see Rowley, 2010.). Differences in returns are based on reduced yields from field planting as well as the absence of price premiums for outof-season strawberries. Differences in supplies are primarily the result of differences in the number of harvest containers required. Labor differences are the result of differences in harvest labor as well as daily tunnel management. Our results indicate that a $125-\mathrm{m}^{2}$ high tunnel would increase net income by $\$ 882$ compared with an equivalent field planting (Table 7). Because net income for the tunnel was $\$ 112.38$, field production of spring-planted day-neutral strawberries resulted in a net loss of $\$ 769.45$ per $125-\mathrm{m}^{2}$ production area.

\section{Conclusions}

The purpose of this study was to develop and evaluate high-tunnel day-neutral strawberry production to extend the season for locally grown fruit. Results showed that high tunnels could be used to improve summer production of spring-planted day-neutral cultivars and extend production into late fall. Of the cultivars evaluated, 'Evie 2' was determined to be most suitable for high-tunnel strawberry production based on higher yields, more uniform seasonal production, and larger berry size than other cultivars evaluated. 'Evie 2' also showed more tolerance to extreme summer heat. 'Seascape' was considered to be the second best option with good yields, good fruit 
size, and greater resistance to gray mold than 'Evie 2'.

Low tunnels inside high tunnels were shown to provide more hours of optimal growing conditions for strawberry plants in the early spring and late fall, but management of the low tunnels to maintain optimum temperatures proved difficult. During the spring, temperatures often exceeded the optimum conditions for strawberry. Shadecloth was shown to decrease temperature by as much as $4{ }^{\circ} \mathrm{C}$ during the hot summer months, thus providing more optimal growing conditions for strawberry plants. Summer replanting with plug plants was not shown to increase fall yields.

The use of low-cost high tunnels converted a spring-planted day-neutral strawberry system from a money-losing to marginally profitable enterprise. However, unless farmers have high demand for late-summer or fall strawberries, this system would not be recommended for the Intermountain West.

\section{Literature Cited}

Ballington, J.R., B. Poling, and K. Olive. 2008. Dayneutral strawberry production for season extension in the Midsouth. HortScience 43:1982-1986.

Black, B., D. Drost, D. Rowley, and R. Heflebower. 2008. Construction a low-cost high tunnel. Utah State University Extension bulletin \# HG/High Tunnels/2008-01pr. Utah State University, Logan, UT. <http://extension.usu.edu/ files/publications/publication>.

Black, B.L., J.M. Enns, and S.C. Hokanson. 2002. A comparison of temperate-climate strawberry production systems using eastern genotypes. HortTechnology 12:670-675.

Demchak, K. 2009. Small fruit production in high tunnels. HortTechnology 19:44-49.

Demchak, K., W.J. Lamont, and M.D. Orzalek. 2006. High tunnel bramble and strawberry culture, p. 126-134. In: High tunnel production manual. Pennsylvania State University, University Park, PA.

Durner, E.F., J.A. Barden, D.G. Himelrick, and E.B. Poling. 1984. Photoperiod and temperature effects on flower and runner development in day-neutral, Junebearing, and everbearing strawberries. J. Amer. Soc. Hort. Sci. 109:396-400.

Galletta, G. 1997. Strawberry, p. 669-737. In: The Brooks and Olmo register of fruit \& nut varieties. ASHS Press, Alexandria, VA.

Galletta, G.J. and R.S. Bringhurst. 1990. Strawberry management, p. 83-156. In: Galletta, G.J. and D.G. Himelrick (eds.). Small fruit crop management. Prentice Hall, Englewood Cliffs, NJ.

Hancock, J. and D. Handley. 1998. The history and biology of the cultivated strawberry, p. 3-6. In: Strawberry production guide for the Northeast, Midwest, and Eastern Canada. Northeast Regional Agricultural Engineering Service (NRAES), Ithaca, NY.

Koester, K. and M. Pritts. 2003. Greenhouse raspberry production guide. Cornell University, Ithaca, NY. 7 Oct. 2011. <http://www.fruit. cornell.edu/berry/production/pdfs/ghrasp.pdf $>$.

McIntosh, G. and G. Klingaman. 1993. A season extension technique for cool season vegetables using poly tunnels and row covers. HortScience 28:269.

Moller, A.L. and R.R. Gillies. 2008. Utah climate. Utah State University, Logan, UT.

Orzolek, M., W. Lamont, and E. Burkhart. 2006. High tunnel vegetable crop production, p. 117125. In: High tunnel production manual. Pennsylvania State University, University Park, PA.

Poling, E.B. 1993. Strawberry plasticulture in North Carolina: II. Preplant, planting, and postplant considerations for growing 'Chandler' strawberry on black plastic mulch. HortTechnology 3:383393.

Pollack, S. and A. Perez. 2008. Fruit and tree nuts situation and outlook yearbook 2008. U.S. Department of Agriculture.
Pritts, M. and A. Dale. 1989. Day neutral strawberry production guide. Information bulletin 215. Cornell Cooperative Extension, Ithaca, NY 7 Oct. 2011. <http://ecommons.cornell.edu>.

Rasmussen, C. and L. White. 2006. High tunnel cut flower production, p. 135-149. In: High tunnel production manual. Pennsylvania State University, University Park, PA.

Roberts, W. and J. Whitworth. 1993. Row covers, watermelon, and hail damage. HortScience 28: 274.

Rowley, D. 2010. Season extension of strawberry and raspberry production using high tunnels. MSc thesis, Utah State University, Logan, UT.

Rowley, D., B. Black, and D. Drost. 2010a. Strawberry plug plant production. Utah State University Extension bulletin Horticulture/ High Tunnels/2010-02pr. Utah State University, Logan, UT. 7 Oct. 2011. <http://extension.usu. edu/publications $>$.

Rowley, D., B.L. Black, D. Drost, and D. Feuz. 2010b. Early-season extension using June-bearing 'Chandler' strawberry plants in high-elevation high tunnels. HortScience 45:1464-1469.

Rowley, D., B.L. Black, and D. Feuz. 2010c. Hightunnel June-bearing strawberry budget 2010 . Utah Agricultural Statistics and Utah Department of Agriculture and Food 2010 Annual Report. Utah Department of Agriculture and Food, Salt Lake City, UT. p. 94.

Shaw, D.V. and K.D. Larson. 2006. Strawberry plant named 'Albion', Patent. The Regents of the University of California, Oakland, CA.

Stevens, M.D., B.L. Black, J.D. Lea-Cox, and D. Feuz. 2011. Horticultural and economic considerations in the sustainability of three cold-climate strawberry production systems. HortScience 46:445-451.

Takeuchi, K. and C.E. Motsenbocker. 2005. The effect of high tunnels and row covers on air temperatures and spring-planted tomato yield in Louisiana. HortScience 40:1055. 